See discussions, stats, and author profiles for this publication at: https://www.researchgate.net/publication/274216018

\title{
A contribution from Barn Owl pellets analysis to known micromammalian distributions in Buenos Aires province, Argentina
}

Article in Mammalia · March 2010

DOI: $10.1515 / \mathrm{mamm} .2009 .069$

\section{CITATIONS}

32

4 authors:

\section{Pablo Teta}

Museo Argentino de Ciencias Naturales "Bernardino Rivadavia"

182 PUBLICATIONS 1,576 CITATIONS

SEE PROFILE

Mariano Codesido

University of Buenos Aires

28 PUBLICATIONS 252 CITATIONS

SEE PROFILE

Some of the authors of this publication are also working on these related projects:
READS

135

72. Carlos Maria Gonzalez Fischer

University of Buenos Aires

20 PUBLICATIONS 262 CITATIONS

SEE PROFILE

David Bilenca

University of Buenos Aires

76 PUBLICATIONS 730 CITATIONS

SEE PROFILE

Impact of hairy armadillo (Chaetophractus villosus) on agricultural activities in the pampas region of Argentina View project

Experimental assessment of bird responses to different farming practices in Buenos Aires province View project 


\section{A contribution from Barn Owl pellets analysis to known micromammalian distributions in Buenos Aires province, Argentina}

\author{
Pablo Teta ${ }^{1, *}$, Carlos M. González-Fischer ${ }^{2}$, Mariano \\ Codesido $^{2}$ and David N. Bilenca ${ }^{2}$ \\ ${ }^{1}$ Museo Argentino de Ciencias Naturales “'Bernardino \\ Rivadavia”, Avenida Ángel Gallardo 470, (C1405DJR) \\ Ciudad Autónoma de Buenos Aires, Buenos Aires, \\ Argentina, e-mail: antheca@yahoo.com.ar \\ 2 Departamento de Ecología, Genética y Evolución, \\ Facultad de Ciencias Exactas y Naturales, Universidad de \\ Buenos Aires, Avenida Intendente Güiraldes 2160, Ciudad \\ Universitaria, Pabellón II, Cuarto piso, (C1428EGA) \\ Ciudad Autónoma de Buenos Aires, Buenos Aires, \\ Argentina \\ *Corresponding author
}

Keywords: agroecosystems; Pampean region; Rodentia; Sigmodontinae; Tyto alba.

The analysis of owl pellet samples is an extremely valuable tool for mammalogists (Yalden and Morris 1990). Studies on this topic around the world are eloquent about the potential and limitations of this methodology. For example, owl pellets can be used for inventorying small mammal communities (Cueto et al. 2008), studying small mammal distribution throughout geographical gradients (Avery et al. 2002, 2005, Pardiñas et al. 2003, Leveau et al. 2006), delimiting distributions on a regional scale (Avery et al. 2002, 2005, Pardiñas et al. 2003, 2004), or to track abundance changes in their preys, both spatially and temporally (Fulk 1976, Love et al. 2000, Millán de la Peña et al. 2003). In addition, owl pellet studies present advantages over traditional survey methods, because raptors can prey on rare species or in species not easily detected with other methods (e.g., traps; Yalden and Morris 1990).

It is usually accepted that micromammalian distributions in the Pampean region of Buenos Aires province, centraleastern Argentina, are relatively well established. However, a detailed study of available information clearly demonstrated that this assertion is partially incorrect (Pardiñas et al. 2004, in press). Much of the work done in this province encompasses part of the northern, eastern, and some southeastern areas, mostly in or near the littoral fringe of La Plata River and the Atlantic coast (Galliari and Goin 1993). How- ever, a very different situation is the norm for the rest of the large territory of the province, including some southern and most of the central portions (Pardiñas et al. 2004, in press).

In this study, we present the results of an extensive small mammal survey conducted in the Pampean region of the Buenos Aires province through the analysis of Barn Owl [Tyto alba Scopoli 1769 (Aves, Tytonidae)] pellet samples. Although these collections were part of another study, it quickly became apparent that they were adding to the known distribution pattern of some micromammals. In addition, we provided some comments regarding species abundance at different localities and the biogeographic implications of some of these records.

The province of Buenos Aires $\left(307,571 \mathrm{~km}^{2}\right)$ is located in central-eastern Argentina, between $33^{\circ}-41^{\circ} \mathrm{S}$ and $57^{\circ}-63^{\circ}$ W. Its territory is almost entirely included within the Pampean eco-region and encompasses four ecological units or districts that can be distinguished according to differences in geomorphology, soils, drainage, physiography, land use patterns, and vegetation: the Rolling Pampa, the Southern Pampa, the Flooding Pampa and the Inland Pampa (Soriano et al. 1992). Native grasslands through most of the Pampean region were gradually converted to agroecosystems over the past two centuries. Primary uses of the land, with some differences between areas, are for agriculture and livestock breeding (see Baldi and Paruelo 2008). Climate of the Pampean region is characterized by an east-west moisture gradient and increasing continentality toward the northwest (Burgos 1968). Mean annual precipitation decreases from $1200 \mathrm{~mm}$ in the northeastern to $600 \mathrm{~mm}$ in the southwestern regions. Mean annual temperatures show a similar trend, with values between $23^{\circ} \mathrm{C}$ (north) and $20^{\circ} \mathrm{C}$ (south) for January and $10^{\circ} \mathrm{C}$ (north) and $7^{\circ} \mathrm{C}$ (south) for June (Burgos 1968).

Fresh Barn Owl pellets were collected during July and August 2006-2007 (winter) and January and February 2007-2008 (summer) from nest sites distributed in the four districts of the Pampean region included in the Buenos Aires province (Figure 1). One to three deposit places were found at each locality. The diet of Tyto alba at the localities of Diego Gaynor and Villa Cacique were previously studied by Bellocq (1990) and Leveau et al. (2004), respectively. All other localities are studied for the first time. Mammalian preys were identified to the lowest taxonomical level possible by the examination of the skull and dentaries, following published literature (Massoia and Fornes 1965, 1969, Mas- 

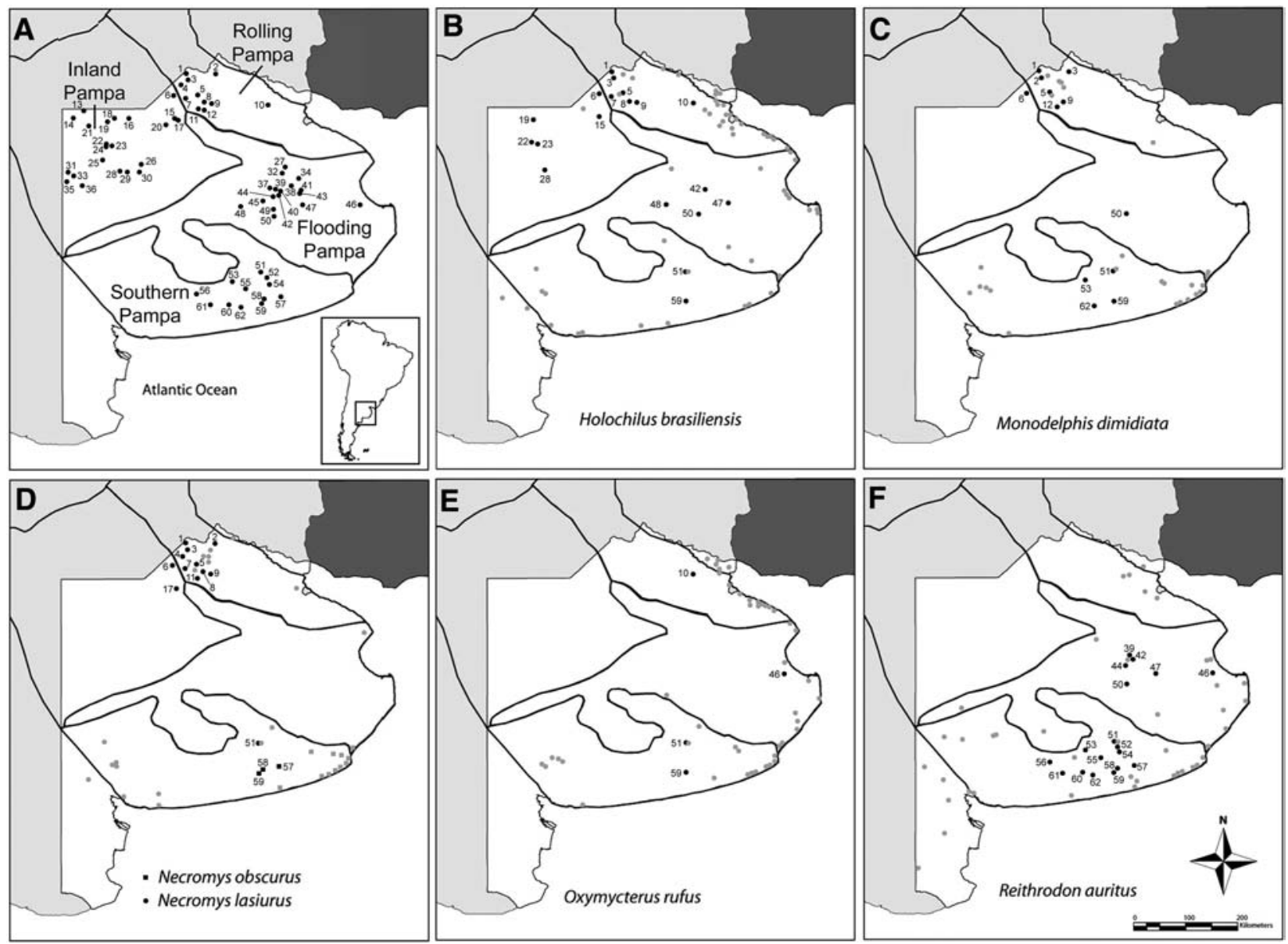

Figure 1 (A) Studied localities and (B-F) new locality records (black circles) for selected micromammal species in Buenos Aires province, central-eastern Argentina. Previous records are shown with gray circles and were compiled from several sources (Massoia 1976, Galliari et al. 1991, Pardiñas 1999, Galliari and Pardiñas 2000, Flores et al. 2007).

soia 1976, Galliari and Pardiñas 2000) and by comparisons with reference collections housed at the Museo de Ciencias Naturales "Bernardino Rivadavia" (Buenos Aires, Argentina). Studied samples are housed in the Laboratorio de Ecología de Poblaciones, Universidad de Buenos Aires (Argentina). The taxonomy employed here follows Wilson and Reeder (2005), with modifications according to D'Elía et al. (2008a).

We analyzed a total of 90 samples from 62 localities identifying a total of 32,892 prey-items. At least 14 taxa are represented in the studied samples (Table 1). In two cases, including the native rodent genus Calomys Waterhouse 1837 and the exotic Rattus Fischer 1803, it was not determined whether one or two species are involved. Two species of Calomys - C. laucha (Fischer 1814) and C. musculinus (Thomas 1913) - are widely sympatric in the Pampean region of the Buenos Aires province (Massoia and Fornes 1965 ), accounting for up to $60 \%$ of the small mammal communities in most of our studied localities. All micromammal species found in the owl pellet samples belonged to species previously cited for the Pampean region (Galliari et al. 1991, Pardiñas et al. in press). The most relevant findings are discussed in the following paragraphs.
Previous records for the small marsupial Monodelphis dimidiata (Wagner 1847) (Figure 2A) correspond to four isolated areas in the north, northeastern, southeastern, and southwestern corners of the province (Flores et al. 2007). Our finding partially fills the gap between the southern populations, enlarging its distribution ca. $90 \mathrm{~km}$ to the west and north from the previous nearest records in this area. In addition, we found this species in the Flooding Pampa, an area without previous references for this species.

New locality records for the marsh rat Holochilus brasiliensis (Desmarest 1819) (Figure 2B) enlarge its distribution ca. $100 \mathrm{~km}$ to the west in the northwestern corner of the Buenos Aires province. In addition, its presence is confirmed in the Flooding and Inland pampas, two areas where the previous records were mostly peripheral (Massoia 1976).

Necromys lasiurus (Lund 1840) (Figure 2C) has a wide and fragmentary distribution in the Pampean region (Galliari and Pardiñas 2000). Our findings in the northern corner of Buenos Aires province expanded ca. $50 \mathrm{~km}$ to the west its known distribution and almost triplicate its range area in this sector. A similar situation was observed with Necromys obscurus (Waterhouse 1837) (Figure 2D). This species enlarged 


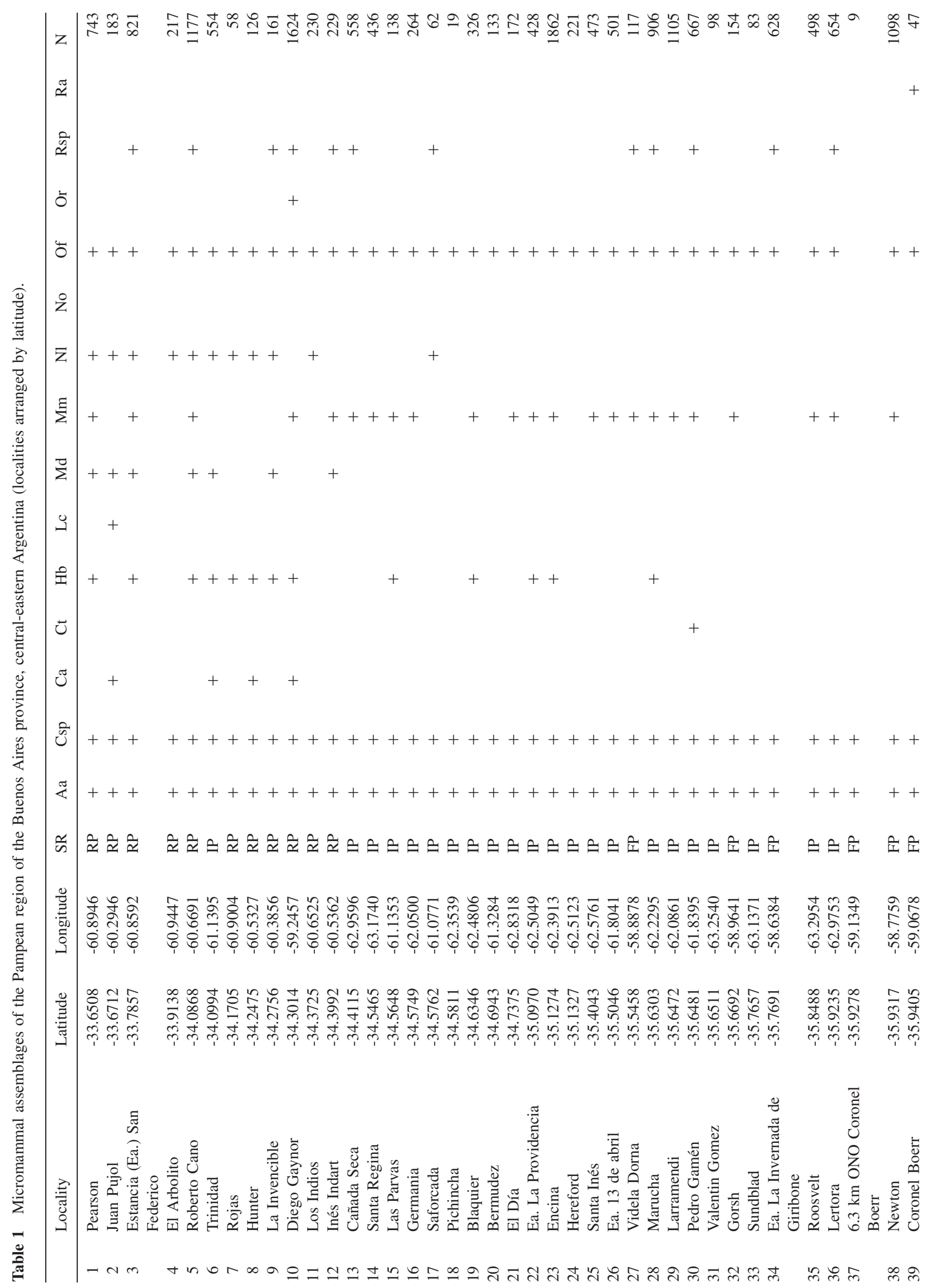




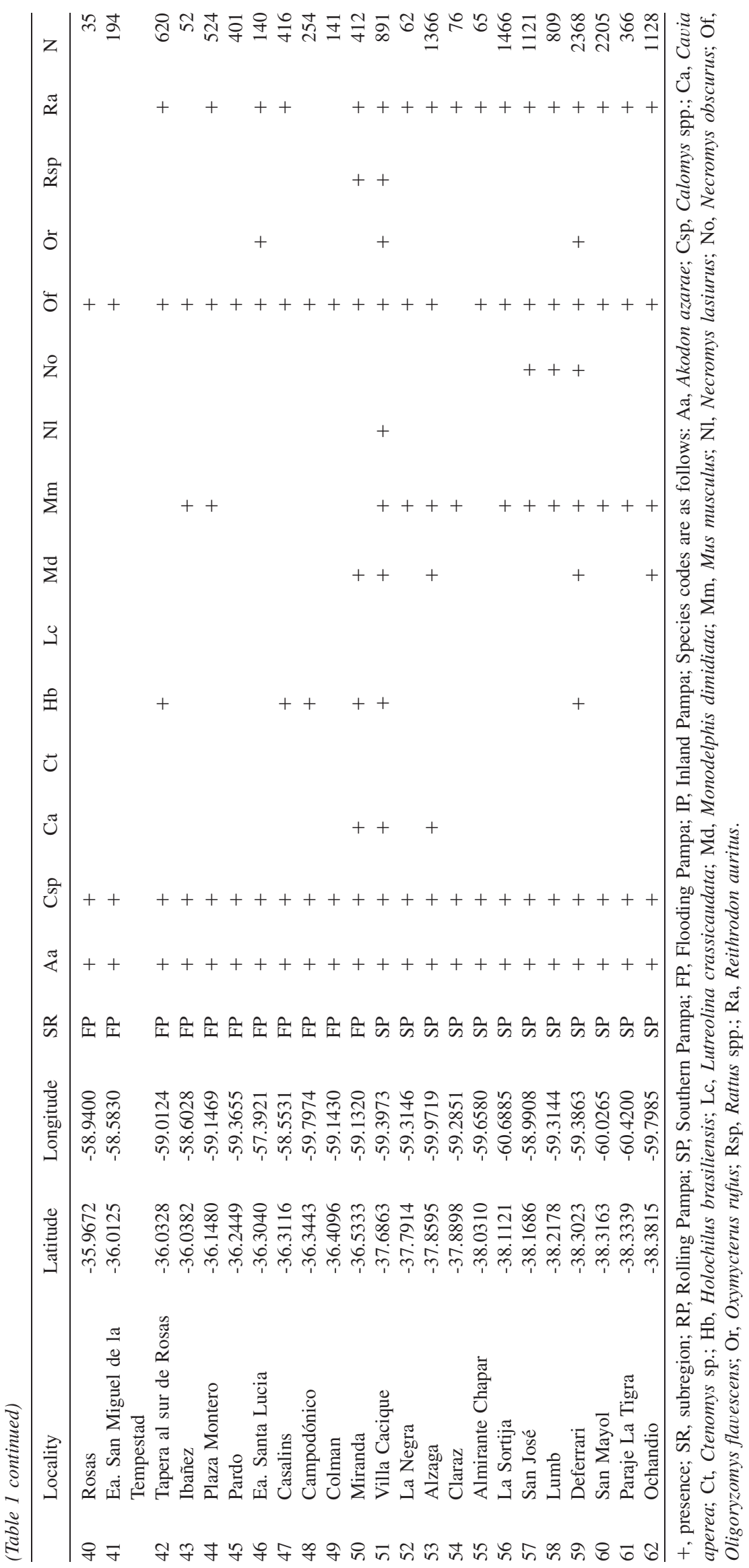




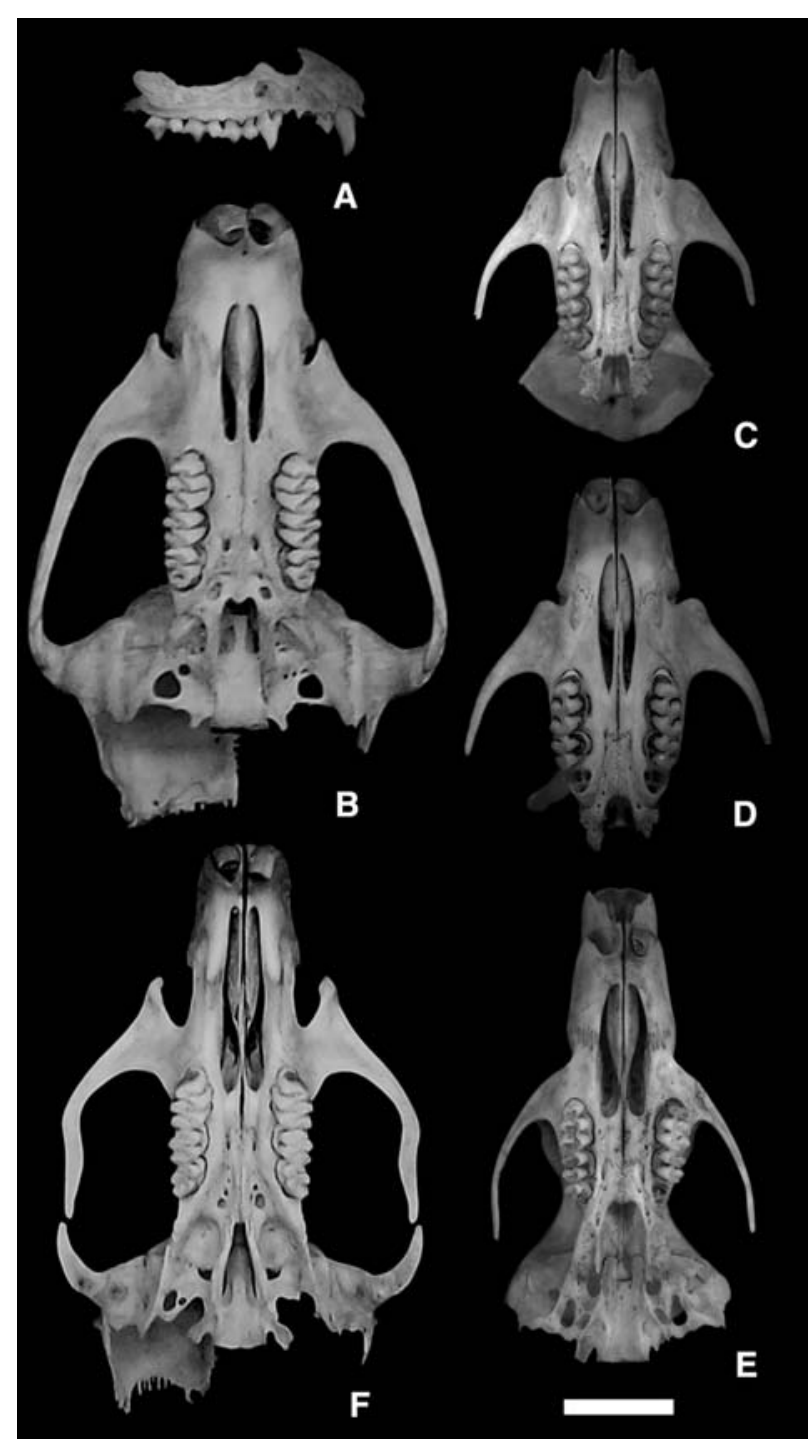

Figure 2 Specimens recovered in the owl pellets from the Pampean region of the Buenos Aires province, Argentina: (A) Monodelphis dimidiata [59], lateral view of the right maxillary; (B) Holochilus brasiliensis [59], ventral view of the skull; (C) Necromys lasiurus [5], ventral view of the skull; (D) Necromys obscurus [59], ventral view of the skull; (E) Oxymycterus rufus [51], ventral view of the skull; (F) Reithrodon auritus [53], ventral view of the skull. The number between brackets corresponds to the locality of collection (see Table 1). Scale $=5 \mathrm{~mm}$.

its distribution to the interior grasslands of the Buenos Aires province ca. $110 \mathrm{~km}$ to the northwest from its previous nearest record. In addition, its small distributional range is almost duplicated in Argentina, restricted to the date to humid grasslands in coastal areas and hilly environments (Galliari and Pardiñas 2000). It is important to note that owing to its restricted and fragmented distribution, this species was listed as Near Threatened by the IUCN (D'Elía et al. 2008b).

Despite that our records for Oxymycterus rufus (Fischer 1814) (Figure 2E) are almost included within the recent range of this species, the reference for Diego Gaynor is noteworthy. The small mammal community of this locality was largely studied in the past three decades and no previous records for this species were made until recent years (Bellocq 1990). In fact, O. rufus was registered for the first time in this area around the decade of 2000 when some individuals were trapped in borders of cultivate fields (Bilenca et al. 2007). Our record is the second for this locality, which is located $40 \mathrm{~km}$ to the south of the nearest previous reference.

Reithrodon auritus (Fischer 1814) (Figure 2F) is mostly restricted to the eastern and southern half of the province. New locality records, showing relatively high frequencies (7-33\% of the total identified specimens) in some sites, fill the gap between previous records in the Flooding and Southern Pampas. This is an interesting finding because $R$. auritus is in general a non-abundant element in the Pampean region (see Prado et al. 1987).

The sigmodontine rodent communities of the Pampean region are characterized by the dominance of Calomys spp., Akodon azarae (Fischer 1819), and Oligoryzomys flavescens (Waterhouse 1837) (Pardiñas et al. in press). Ecological, genetic, and paleontological studies have associated the prevalence of these species, and in particular of Calomys spp., with the transformation of large surfaces from natural pastures and grasslands to crop fields (Pardiñas 1995, 1999, González-Ittig et al. 2007, Pardiñas et al. in press). This situation created favorable conditions for Calomys spp., allowing populations to increase in size and to expand (Bilenca and Kravetz 1995, Pardiñas 1995). These same conditions were perhaps responsible for the fragmentation of the distributional ranges of some species, including local (e.g., Necromys lasiurus in some coastal areas; see Galliari and Pardiñas 2000) or total extinctions, and the decrease in the abundance of others (e.g., Reithrodon auritus; Pardiñas 1999). Our survey, encompassing a surface of ca. $150,000 \mathrm{~km}^{2}$ of mostly unstudied areas, confirms this assertion. In fact, despite that we found a significant extension of range distributions for some species, the main distributional patterns do not change significantly (e.g., Necromys lasiurus is still restricted to four main discontinuous populations).

Our data confirm the importance of Tyto alba in recording small mammals and show that the analysis of regurgitated pellets can be an important tool for the inventory of rare or difficult-to-trap small mammals. This methodology permits to sample small mammal communities through very large areas at low cost, allowing detection of isolated populations of species with fragmentary distributions. Moreover, samples through different years are useful to detect small mammal changes in the communities, such as range expansions or extinctions, both at local and regional levels. In addition, taking into account the recent changes observed in the Pampean biota with regard to different land use and landscape structure (Attademo et al. 2005, Schrag et al. 2009), owl pellet analysis can be a valuable tool in evaluating the evolution of small mammal composition in short-term periods (Love at al. 2000).

\section{Acknowledgements}

We would like to thank Lucas and Carlos Leveau, Laura Solari and Jennifer Tregoning for their assistance during fieldwork. Ulyses F.J. 
Pardiñas and an anonymous reviewer made valuable comments on a first draft of this work. This study was funded by the Consejo Nacional de Investigaciones Científicas y Técnicas (CONICET, Argentina), the Universidad de Buenos Aires (grants UBACyT X282 and X406), and the Instituto Nacional de Tecnología Agropecuaria (INTA, Argentina; PNECO 1302).

\section{References}

Attademo, A.M., P.M. Peltzer and R.C. Lajmanovich. 2005. Amphibians occurring in soybean and implications for biological control in Argentina. Agric. Ecosyst. Environ. 106: 389-394.

Avery, D.M., G. Avery and A. Roberts. 2002. A contribution from barn owl pellets to known micromammalian distributions in KwaZulu-Natal, South Africa. Afr. Zool. 37: 131-140.

Avery, D.M., G. Avery and N.G. Palmer. 2005. Micromammalian distribution and abundance in the Western Cape Province, South Africa, as evidenced by Barn Owls Tyto alba (Scopoli). J. Nat. Hist. 39: 2047-2071.

Baldi, G. and J.M. Paruelo. 2008. Land-use and land cover dynamics in South American temperate grasslands. Ecol. Soc. 13: 6, online at http://www.ecologyandsociety.org/vol13/iss2/art6/.

Bellocq, M.I. 1990. Composición y variación temporal de la dieta de Tyto alba en ecosistemas agrarios pampeanos, Argentina. Vida Silvestre Neotrop. 2: 32-35.

Bilenca, D.N. and F.O. Kravetz. 1995. Patrones de abundancia relativa en ensambles de pequeños roedores de la región pampeana. Ecol. Austral 5: 21-30.

Bilenca, D.N, C.M. Gonzalez-Fischer, P. Teta and M. Zamero. 2007. Agricultural intensification and small mammal assemblages in agroecosystems of the Rolling Pampas, central Argentina. Agric. Ecosyst. Environ. 121: 371-375.

Burgos, J.J. 1968. El clima de la provincia de Buenos Aires en relación con la vegetación natural y el suelo. In: (A.L. Cabrera, ed.) Flora de la provincia de Buenos Aires. Vol. 4 (1), Colección Científica. Instituto Nacional de Tecnología Agropecuaria, Buenos Aires, Argentina. pp. 33-99.

Cueto, G.R., P. Teta and P. De Carli. 2008. Rodents from southern Patagonian semi-arid steppes (Santa Cruz Province, Argentina). J. Arid Environ. 72: 56-61.

D’Elía, G., U.F.J. Pardiñas, J.P. Jayat and J. Salazar-Bravo. 2008a. Systematics of Necromys (Rodentia, Cricetidae, Sigmodontinae): species limits and groups, with comments on historical biogeography. J. Mammal. 89: 778-790.

D’Elía, G., U.F.J. Pardinas, J.P. Jayat, P. Teta and B. Patterson. 2008b. Necromys obscurus. In: IUCN 2009. IUCN red list of threatened species. Version 2009.1. Available at: www.iucnredlist. org (downloaded on 27 July, 2009).

Flores, D.A., M.M. Díaz and R. Barquez. 2007. Systematics and distribution of marsupials in Argentina: a review. Univ. Calif. Publ. Zool. 134: 579-669.

Fulk, G.W. 1976. Owl predation and rodent mortality: a case of study. Mammalia 40: 423-427.

Galliari, C.A. and F. Goin. 1993. Conservación de la Biodiversidad en la Argentina: el caso de los mamíferos. In: (F. Goin and R. Goñi, eds.) Elementos de Política Ambiental. Honorable Cámara de Diputados de la provincia de Buenos Aires, Argentina. pp. 367-400.

Galliari, C.A. and U.F.J. Pardiñas. 2000. Taxonomy and distribution of the sigmodontine rodents of genus Necromys in central Argentina and Uruguay. Acta Theriol. 45: 211-232.
Galliari, C.A., W.D. Berman and F.J. Goin. 1991. Situación ambiental de la provincia de Buenos Aires. A. Recursos y rasgos naturales en la evaluación ambiental. Mamíferos. Comisión de Investigaciones Científicas de la provincia de Buenos Aires, año I, 5: 1-35.

González-Ittig, R.E., J.L. Patton and C.N. Gardenal. 2007. Analysis of cytochrome-b nucleotide diversity confirms a recent range expansion in Calomys musculinus (Rodentia, Muridae). J. Mammal. 88: 777-783.

Leveau, L.M., C.M. Leveau and U.F.J. Pardiñas. 2004. Trophic relationships between White-tailed Kites (Elanus leucurus) and Barn Owls (Tyto alba) in southern Buenos Aires province, Argentina. J. Raptor Res. 38: 178-181.

Leveau, L.M., P. Teta, R. Bogdaschewsky, U.F.J. Pardiñas. 2006. Feeding habits of the Barn Owl (Tyto alba) along a longitudinallatitudinal gradient in Central Argentina. Ornitol. Neotrop. 17: 353-362.

Love, R.A., C. Webbon, D.E. Blue and S. Harris. 2000. Changes in the food of British Barn Owls (Tyto alba) between 1947 and 1997. Mammal Rev. 30: 107-129.

Massoia, E. 1976. Mammalia. In: (R. Ringuelet, dir.) Fauna de agua dulce de la República Argentina. Fundación Editorial Ciencia y Cultura, Buenos Aires, Argentina. pp. 1-128.

Massoia, E. and A. Fornes. 1965. Contribución al conocimiento de los roedores miomorfos argentinos vinculados con la fiebre hemorrágica argentina. Ministerio de Asuntos Sociales y Salud Pública de la Nación, Difusión de la Comisión Nacional Coordinadora para el Estudio y Lucha contra la Fiebre Hemorrágica Argentina. pp. 24

Massoia, E. and A. Fornes. 1969. Claves para el reconocimiento de los roedores del Delta del Paraná (Mammalia). Instituto Nacional de Tecnología Agropecuaria, IDIA 253: 11-18.

Millán de la Peña, N., A. Butet, Y. Delettre, G. Paillat, P. Morant, L. Le Du and F. Burel. 2003. Response of the small mammal community to changes in western French agricultural landscapes. Landsc. Ecol. 18: 265-278.

Pardiñas, U.F.J. 1995. Capítulo 11. Los roedores cricétidos. In: (M.T. Alberdi, G. Leone and E.P. Tonni, eds.) Evolución climática y biológica de la región pampeana durante los últimos cinco millones de años. Un ensayo de correlación con el Mediterráneo occidental, Museo Nacional de Ciencias Naturales, CSIC, Monografías 14, Madrid. pp. 229-256.

Pardiñas, U.F.J. 1999. Los roedores muroideos del Pleistoceno tardío-Holoceno en la región pampeana (sector este) y Patagonia (República Argentina): aspectos taxonómicos, importancia bioestratigráfica y significación paleoambiental. Doctoral dissertation, Facultad de Ciencias Naturales y Museo, Universidad Nacional La Plata, La Plata, Argentina.

Pardiñas, U.F.J., P. Teta, S. Cirignoli and D.H. Podestá. 2003. Micromamíferos (Didelphimorphia y Rodentia) de norpatagonia extra andina, Argentina: taxonomía alfa y biogeografía. Mastozool. Neotrop. 10: 69-113.

Pardiñas, U.F.J., A.M. Abba and M.L. Merino. 2004. Micromamíferos (Didelphimorphia y Rodentia) del sudoeste de la provincia de Buenos Aires (Argentina): taxonomía y distribución. Mastozool. Neotrop. 11: 211-232.

Pardiñas, U.F.J., P. Teta and D.N. Bilenca. In press. Roedores sigmodontinos de la región pampeana: una introducción zoogeográfica. In: (J. Polop and M. Busch, eds.) Biología de los roedores sigmodontinos de la región pampeana (Argentina). Universidad Nacional de Río Cuarto, Río Cuarto, Córdoba.

Prado, J.L., A.N. Menégaz, E.P. Tonni and M.C. Salemme. 1987. 
Los mamíferos de la Fauna Local Paso Otero (Pleistoceno tardío), provincia de Buenos Aires. Aspectos paleoambientales y bioestratigráficos. Ameghiniana 24: 217-233.

Schrag, A.M., M.E. Zaccagnini, N. Calamari and S. Canavelli. 2009. Climate and land-use influences on avifauna in central Argentina: broad-scale patterns and implications of agricultural conversion for biodiversity. Agric. Ecosyst. Environ. 132: 135-142.

Soriano, A., R.J.C. León, O.E. Sala, R.S. Lavado, V.A. Deregibus, M.A. Cahuépé, O.A. Scaglia, C.A. Velázquez and J.H. Lemcoff.
1992. Río de la Plata grasslands. In: (R.T. Coupland, ed.) Ecosystems of the world 8A. Natural grasslands. Introduction and western hemisphere. Elsevier, New York. pp. 367-407.

Wilson, D.E. and D.M. Reeder (ed.) 2005. Mammal species of the World. Johns Hopkins University Press, Baltimore, MD. pp. 2142.

Yalden, D.W and P.A. Morris. 1990. The analysis of owl pellets. An Occasional Publication of the Mammal Society, London. pp. 36. 